\title{
A report of hybridisation in Hymenachne (Poaceae, Panicoideae) with description of Hymenachne $\times$ calamitosa, a new species of hybrid origin from tropical Australia
}

\author{
John R. Clarkson', Mirko Karan² and Darren S. Evans ${ }^{2}$ \\ ${ }^{1}$ Department of Environment and Resource Management, PO Box 156, \\ Mareeba, Qld 4880, Australia, \\ ${ }^{2}$ Department of Employment, Economic Development and Innovation, PO Box 1054, \\ Mareeba, Qld 4880, Australia
}

\begin{abstract}
Naturally occurring hybridisation between the introduced species Hymenachne amplexicaulis, a Weed of National Significance, and the Australian native species H. acutigluma is reported from two widely separated locations in tropical Australia. Molecular studies including RAPD analysis and DNA sequencing of the ITS region of each parent species and the putative cross confirm initial evidence for hybridisation based on gross morphology. The legislative implications of this are discussed and the species of hybrid origin is described as Hymenachne $\times$ calamitosa J.R. Clarkson.
\end{abstract}

\section{Introduction}

Hymenachne P. Beauv. is a genus of perennial aquatic grasses established in 1812 based on Agrostis monostachya Poir. (syn. H. amplexicaulis (Rudge) Nees). Confusion regarding the typification of the genus was resolved by Panigrahi and Dubey (1986). The genus lies within the large, well supported, monophyletic subfamily Panicoideae (Grass Phylogeny Working Group 2001). It was placed in subtribe Setarinae by Clayton and Renvoize (1986), however recent phylogenetic analyses by Kellogg (2002) have shown that their subtribes are not monophyletic and should not be recognised.

There is some dispute as to the number of species within the genus, however the most recent literature suggests there are approximately 10 (Aliscioni et al. 2003). Species are found in tropical and subtropical regions of the Asiatic tropics, the Pacific Islands, and Central and South America (Pohl and Lersten 1975). Two species are known to occur in Australia. Hymenachne acutigluma (Steud.) Gilliland occurs naturally in coastal and near coastal areas of Queensland from Sarina (latitude $21^{\circ}$ South) to the mouth of the Archer River on Cape York Peninsula (latitude $13^{\circ}$ South) and across the Top End of the Northern Territory from the Goromuru River in Eastern Arnhem Land (longitude $136^{\circ}$ East) to the Daly River (longitude $130^{\circ}$ East). Its range extends to tropical Asia. 
A second species of South American origin, Hymenachne amplexicaulis (Rudge) Nees, introduced as a pasture species, has become naturalised in parts of Queensland, Northern Territory and New South Wales. It is a declared weed in all Australian states and territories and is one of 20 species listed as Weeds of National Significance (Australian Weeds Committee 2009). The introduction, use and subsequent spread of this species in Australia have been reviewed by Wearne et al. (2010). There has been some confusion in the past regarding the use of the name Hymenachne amplexicaulis by Australian botanists. Prior to the publication of Webster's (1987) book describing Australian Paniceae, the name H. amplexicaulis was applied incorrectly to the Australian native species (for example by White 1932 and Blake 1954) but this has subsequently been corrected in all the herbarium specimens seen by the authors.

The spread of $H$. amplexicaulis in Australia can probably be traced to experimental trials and plantings on grazing properties from seed introduced in 1973 as CPI 61149 (Broué 1973) from the International Research Institute, Tucupita, Venezuela. There is some doubt as to the original source of this material. It is thought to have been either Haiti or the Dominican Republic (Oram 1989). No herbarium records exist prior to 1987 suggesting material from an earlier introduction in 1934 (CPI 5820) was either incorrectly identified as $H$. amplexicaulis, never released from quarantine or died out before it could escape trial sites (Wearne et al. 2010). Given its weedy traits, it was inevitable that the introduced species would spread to wetlands where the native species $H$. acutigluma occurred. This was first recorded at Abattoir Swamp near Julatten in Far North Queensland. H. acutigluma forms dense stands there (J.R. Clarkson 10306, BRI AQ595947). A single plant of H. amplexicaulis (J.R. Clarkson 10314, BRI AQ595951) was located in the swamp in May 1995 apparently spread to there by waterbirds from a nearby planted source. This was removed when discovered, but reinfestation resulted in a well established population within 12 months. In 2007 JRC noticed plants in Abattoir Swamp which seemed intermediate in appearance to the two species present (Fig. 1). The gross morphology of these plants strongly suggested they might be of hybrid origin. The aim of this study was to provide molecular evidence to confirm this suspicion.

\section{Materials and Methods}

The primary material for this study was obtained from Abattoir Swamp, $4.5 \mathrm{~km}$ north of Mount Molloy. Approximately $30 \mathrm{~mm}$ long terminal portions of emergent stems including the apical bud were collected from four individuals of each parent species and the putative hybrid and immediately transferred to small vials containing a nucleic acid preserving solution RNAlater (Ambion Inc).

Subsequent to analyses of the Queensland material, reports of suspected hybrids were received from two sites in the Northern Territory (Natasha Burrows pers. comm.). These were located at Beatrice Creek, east of Humpty Doo on the Arnhem Highway and Manton Dam $52 \mathrm{~km}$ south east of Darwin. JRC visited both sites in May 2009. Plants of suspected hybrid origin were located at Beatrice Creek while plants at Manton Dam were clearly $H$. amplexicaulis and $H$. acutigluma. Terminal stem portions were collected from plants at both sites including material of $H$. amplexicaulis growing close to the putative hybrid at Beatrice Creek. Immediately following collection, samples were split into two subsets. One set was transferred to small vials containing silica gel and one to vials containing RNAlater. These samples were presented for molecular analyses with coded labels which hid their field identifications. 
Vouchers for all populations are listed in Appendix 1. These will be deposited at the Queensland Herbarium, Toowong.

\section{DNA}

A wide range of molecular technologies have been used to study interspecific hybridisation (Hegarty \& Hiscock 2005). Two of the most commonly used methods are the sequence comparisons of nuclear ribosomal DNA internal transcribed spacer (ITS) regions (Peterson et al. 2009, Rauscher et al. 2002, Aguilar et al. 1999) and Random Amplified Polymorphic DNA (RAPD) assessments (Yüzbaşioğlu et al. 2008, Lee et al. 2006, González-Rodríguez et al. 2004, Ayres et al. 1999, Arnold 1993). We adopted both approaches in this study to provide clarity and confidence in the results.

\section{DNA extraction}

Leaf tissue was disrupted with a bead beater (TissueLyser II, Qiagen) in the presence of buffer PL1 before column purification of DNA with NucleoSpin Plant II kit (Machery Nagel) as per the manufacturer's instructions.

\section{Amplification and sequencing of ITS regions}

Nuclear ribosomal DNA internal transcribed spacer (ITS) regions were amplified using primers described in Sun et al. (1994) with PCR conditions as described by Torres González and Morton (2005). The region amplified included the 5.8S and part of the $18 \mathrm{~S}$ and $26 \mathrm{~S}$ rDNA. Amplified products were purified by column chromatography

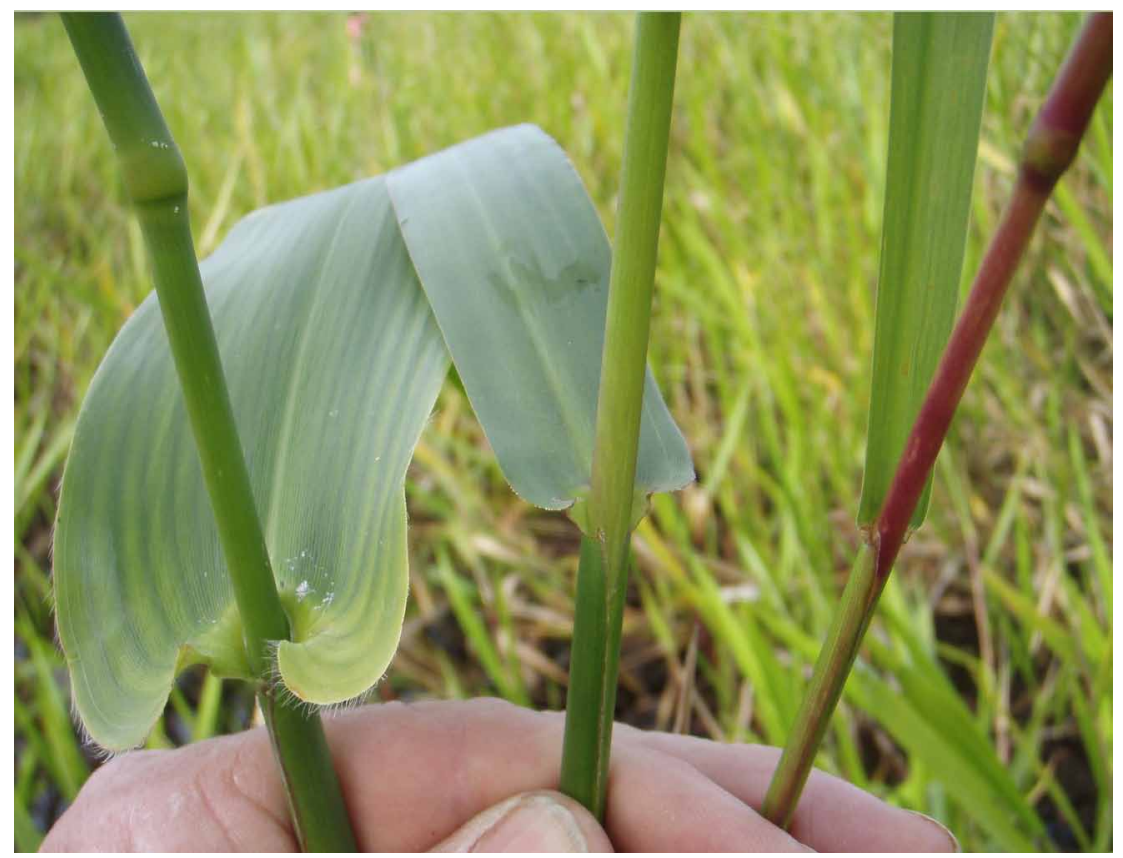

Fig. 1. Leaf blade bases of Hymenachne spp. Left to right: H. amplexicaulis (Clarkson 11787), H. $\times$ calamitosa (Clarkson 11789) and H. acutigluma (Clarkson 11788). 
(Wizard SV Gel \& PCR Clean Up System, Promega) and sequenced directly by an external service (Macrogen Inc. Korea). Amplified products were also cloned into pGEM-Teasy plasmid vector (Promega) as per the manufacturer's instructions and sequenced (Macrogen Inc. Korea).

DNA sequences were analysed using MacVector version 10.5 software (MacVector Inc.) and multiple alignments produced with the Clustal W (v1.83) module (Thompson et al. 1994).

\section{Random Amplification of Polymorphic DNA}

Primers for RAPD analyses (OPA-01, OPA-11, OPA-14, OPA-17, OPA-18, OPAS10, OPB-01, OPB-07, OPB-12, OPB-13 and OPX-04) were obtained from Operon Biotechnologies. PCR reactions contained PCR buffer (Fermentas), $3 \mathrm{mM} \mathrm{MgCl}$, $0.5 \mu \mathrm{M}$ primer, $0.25 \mathrm{mM}$ dNTPs and $1.5 \mathrm{U}$ Taq polymerase (Fermentas) and $10 \mathrm{ng}$ DNA template in a total volume of $20 \mu \mathrm{L}$. The PCR reaction conditions consisted of an initial denaturation step at $94^{\circ} \mathrm{C}$ for $3 \mathrm{~min}$, followed by ten cycles of $94^{\circ} \mathrm{C}$ for $30 \mathrm{sec}$, $60^{\circ} \mathrm{C}$ for $1 \mathrm{~min}$ (decreasing by $1^{\circ} \mathrm{C} /$ cycle), $72^{\circ} \mathrm{C}$ for $90 \mathrm{sec}$, flowed by $30 \mathrm{cycles}$ of $94^{\circ} \mathrm{C}$ for $30 \mathrm{sec}, 50^{\circ} \mathrm{C}$ for $1 \mathrm{~min}, 72^{\circ} \mathrm{C}$ for $90 \mathrm{sec}$ and a final extension step of $72^{\circ} \mathrm{C}$ for $10 \mathrm{~min}$. Amplification products were resolved using $1.5 \%$ agarose gels, stained with ethidium bromide and visualised under UV light.

\section{Results}

\section{ITS sequence analysis}

An 846 bp region of ribosomal DNA containing ITS1 and ITS2 regions was amplified from $H$. amplexicaulis, $H$. acutigluma and the putative hybrid. This DNA fragment was cloned and a number of individual recombinant clones sequenced for each taxon. The sequence alignment showed a high level of sequence similarity with 16 variable sites that differentiated $H$. amplexicaulis and $H$. acutigluma (Table 1 ). Two of the sequences derived from the putative hybrid were identical to $H$. amplexicaulis and five of the sequences were identical to $H$. acutigluma. The initial eight variable sites (positions 199-335) are located in the ITS1 region, one variable site (position 488) is in the 5.8S region and the terminal seven variable sites (positions 599-681) are located in ITS2. Positions of ITS1 and ITS2 were inferred by sequence alignments with published sequences (data not shown).

The presence of two different sequences from the putative hybrid indicates that these represented one copy from each parent. To test this hypothesis we amplified the 846 bp ITS region from each plant and directly sequenced the amplification products. A comparison of sequence chromatograms covering three variable sites in ITS1 (Fig. 2a) and three variable sites in ITS2 (Fig. 2b) in H. amplexicaulis and H. acutigluma showed no base ambiguities at these positions. The chromatograms for the putative hybrid show two overlapping peaks at each of the variable sites that correspond to $H$. amplexicaulis and $H$. acutigluma specific sequence, indicating the presence of both parental bases at these positions (Fig. 2). 

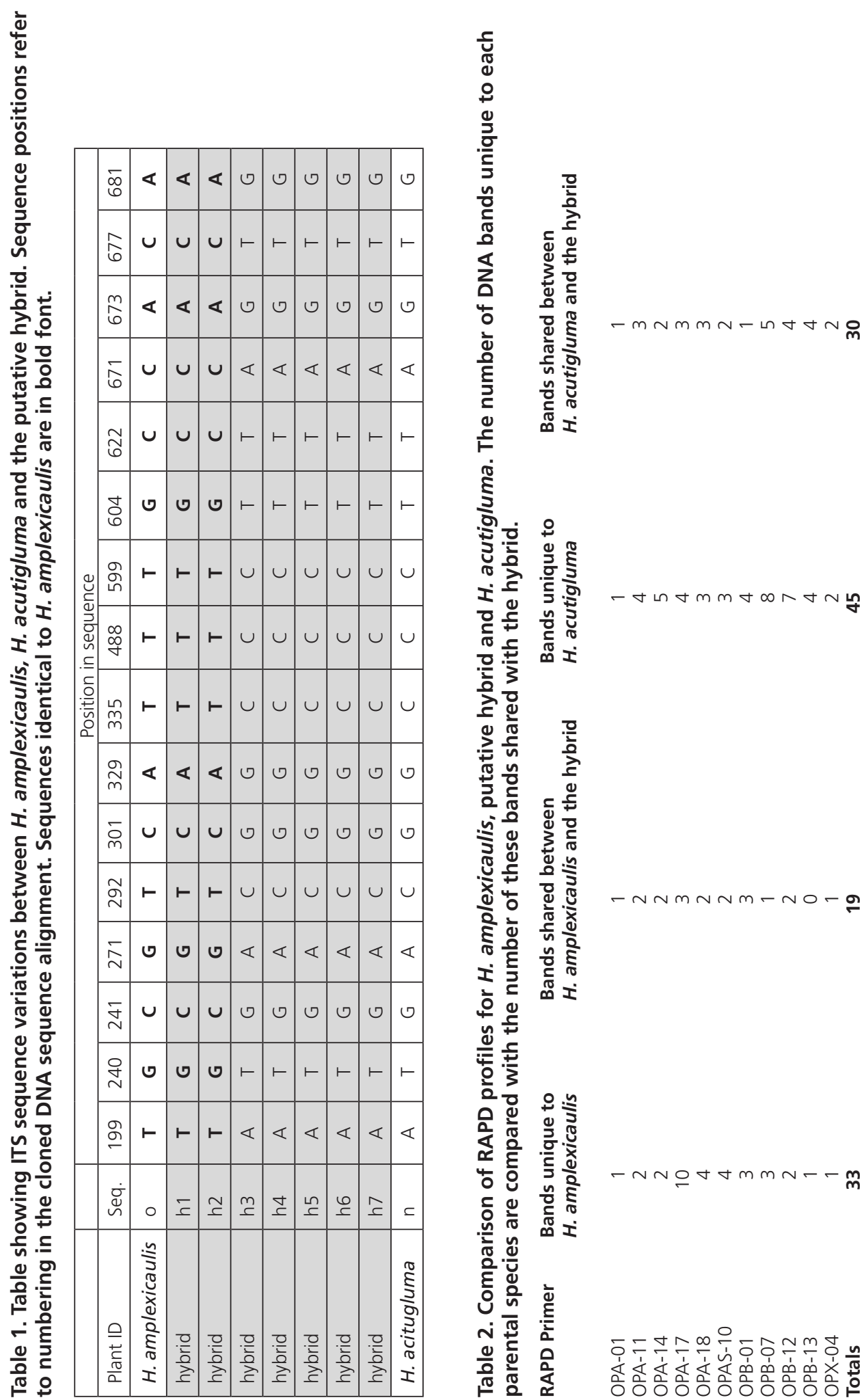
$2 \mathrm{~A}$

H. amplexicaulis
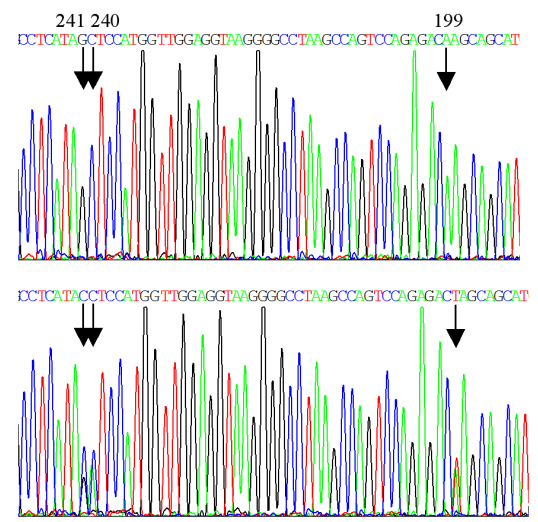

H. x calamitosa

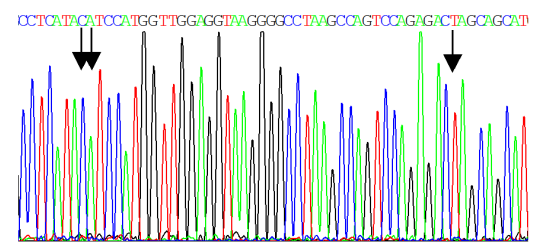

H. acitugluma

$622 \quad 604599$

2B

H. amplexicaulis

H. x calamitosa
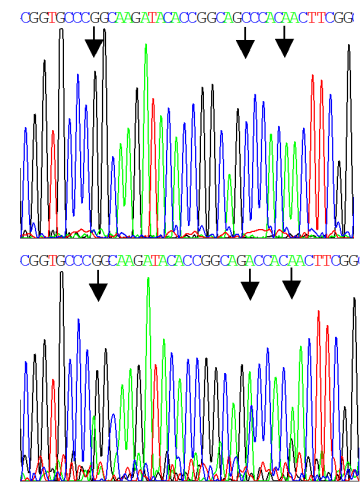

CGGIOCOCAGCAAGATACACCGGCAGACCACGACTTCGG

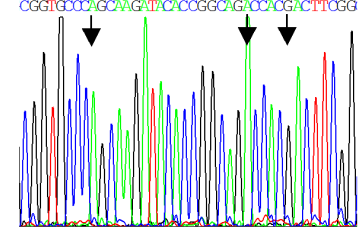

Fig 2. Direct PCR sequence chromatograms for ITS1 (2A) and ITS2 (2B) regions of Hymenachne amplexicaulis, $H$. acutigluma and putative hybrid showing presence of single and dual peaks at variable sites. Numbering refers to sequence alignment (Table 1) (sequences are in reverse complement orientation). 


\section{RAPD analysis}

DNA was extracted from samples obtained from two individuals of H. amplexicaulis, two plants of the putative hybrid and three $H$. acutigluma plants. RAPD analysis with 11 PCR primers produced banding patterns that were conserved within each species with a number of bands unique to $H$. amplexicaulis (33 bands) and $H$. acutigluma (45 bands) (Fig. 3, Table 2). All of the DNA bands amplified from the putative hybrid co-occurred in either $H$. amplexicaulis or $H$. acutigluma banding patterns. Of the 78 DNA bands that differentiated $H$. amplexicaulis and H. acutigluma, 49 were also present in the putative hybrid (Fig. 3, Table 2).

Comparisons of $H$. amplexicaulis and $H$. acutigluma isolates from the Northern Territory material indicated a high level of similarity of RAPD profiles when compared to the Far North Queensland isolates. RAPD profiles were generated with eight of the PCR primers used in the study of the Queensland material resulting in 20 of 24 $H$. amplexicaulis specific bands and 25 of $29 \mathrm{H}$. acutigluma specific bands detected. Of the eight Northern Territory samples, four were identified as H. amplexicaulis, four as $H$. acutigluma and two of hybrid origin. The RAPD profiles for all samples agreed fully with the field identifications.

\section{Discussion}

The RAPD data clearly indicate a strong genetic relationship between the hybrid and the two putative parent species. The DNA banding patterns of the putative hybrid were made up of fragments also found in the proposed parental species, $58 \%$ of the DNA bands unique to $H$. amplexicaulis and $67 \%$ of bands unique to $H$. acutigluma were shared with the putative hybrid.

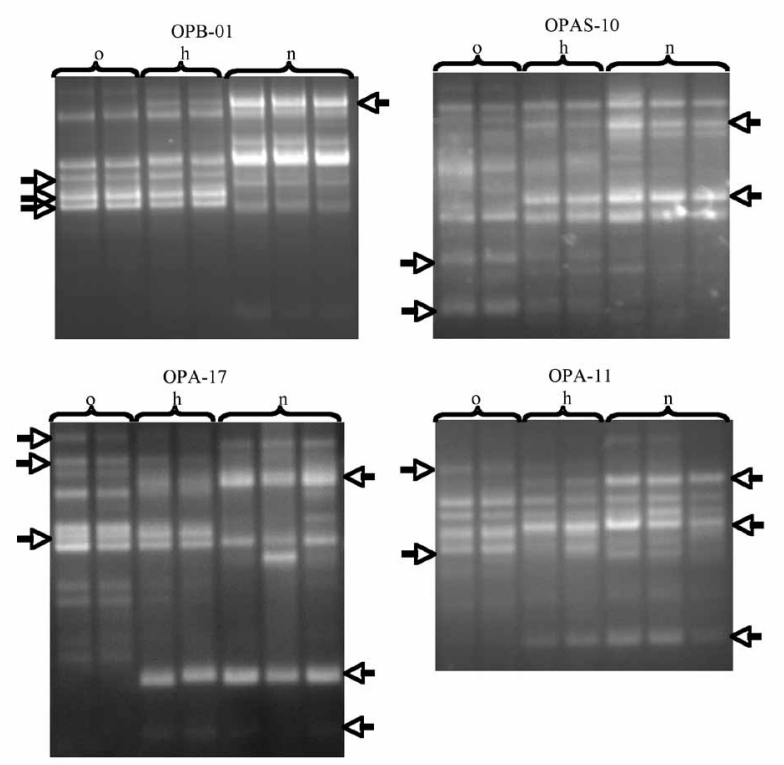

Fig 3. Examples of RAPD patterns in 1.5\% agarose gels showing DNA banding patterns for Hymenachne amplexicaulis (o), putative hybrid (h) and H. acutigluma (n). Unique bands of each species parent that also occur in the hybrid are marked with arrows. 
It is yet to be determined whether the putative hybrid is fertile. The higher number of bands shared with $H$. acutigluma may indicate backcrossing to this species or self fertilisation. It is also possible that this pattern is an artefact of the small data set. Considering the available evidence, it is not clear whether the putative hybrid has undergone backcrossing events. Further research on the fertility of the putative hybrid is required.

Plants of hybrid origin have been identified from two widely separated localities in Northern Australia so hybridisation between these species may not be an unusual event. It is likely to occur anywhere the two species occur in close proximity for any length of time. Field observations suggest the hybrid will be at least as invasive under Australian conditions as $H$. amplexicaulis and should be dealt with accordingly.

\section{Implications for Legislation}

Although Hymenachne amplexicaulis is a declared pest plant in all Australian states and territories, it is not clear whether hybrids with this species as a parent are automatically included in these declarations. Declarations may have to be amended to specifically include the hybrid. There would appear to be three options:

change the declaration in all jurisdictions to include all species of the genus Hymenachne other than the native species H. acutigluma,

change the declaration in all jurisdictions to specifically include all hybrids with $H$. amplexicaulis as one of the parents, or

formally describe the hybrid and declare this in all jurisdictions.

Under legislation currently in force in Queensland - Land Protection (Pest and Stock Route Management) Act 2002 and Land Protection (Pest and Stock Route Management) Regulation 2003, there are precedents for all three options. All Striga species other than native species are declared Class 1 pests, Jatropha gossypifolia L. and hybrids with this species are declared Class 2 pests and the hybrid Bryophyllum daigremontianum (Raym.-Hamet \& H.Perrier) A.Berger $\times$ B.delagoense (Eckl. \& Zeyh.) Schinz is declared Class 2 under the name Bryophyllum $\times$ houghtonii (D.B.Ward) P.I.Forst. We suggest the last is the simplest and therefore most appropriate course of action and here describe the hybrid resulting from the crossing of $H$. amplexicaulis and H. acutigluma as Hymenachne $\times$ calamitosa and recommend declaration in all jurisdictions without undue delay.

\section{Species description}

Hymenachne $\times$ calamitosa J.R. Clarkson, sp. nov.

Hybrida naturalis e Hymenachne amplexicaulis (Rudge) Nees et Hymenachne acutigluma (Steud.) Gilliland exorta, latitudine folii et aliis characteribus inter parentes media, ad illud habitu accedens sed base folii non amplexicauli.

Holotype: Queensland: Cook; Abattoir Swamp, 4.5km north of Mount Molloy (16³8'09"S, 145¹9'37"E), J.R. Clarkson 11796, 12 May 2009 (BRI). Isotypes: CNS, DNA, K, L, MO, NSW, PERTH.

Etymology: the specific epithet is from the Latin calamitosus meaning destructive, disastrous or ill-fated hence marked by or promising bad fortune. This is an allusion to 
the propensity for the hybrid to be at least as invasive and environmentally destructive under Australian conditions as one of its parents, H. amplexicaulis.

Notes: descriptions of $H$. acutigluma and H. amplexicaulis and a key to distinguish them are provided by Cowie et al. (2000). The hybrid appears to be intermediate between the parents in all characters. The leaves are broader than those of H. acutigluma, narrower than $H$. amplexicaulis and lack the stem-clasping leaf bases of the latter.

\section{Acknowledgments}

Les Pedley, Darren Crayn and Katharina Schulte kindly read and provided useful comments on the manuscript. Piers Barrow provided logistical support to visit Hymenachne sites in the Northern Territory. John Clarkson would like to especially acknowledge the help and encouragement provided by his long time friend and colleague Surrey Jacobs.

\section{References}

Aguilar JF, Rosselló JA \& Feliner GN (1999) Nuclear ribosomal DNA (nrDNA) concerted evolution in natural and artificial hybrids of Armeria (Plumbaginaceae). Molecular Ecology 8: 1341-1346.

Alisciono SS, Giussani LM, Zuloaga FO \& Kellogg EA (2003) A molecular phylogeny of Panicum (Poaceae: Paniceae): tests of monophyly and phylogenetic placement within the Panicoideae. American Journal of Botany 90: 796-821.

Arnold ML (1993) Iris nelsonii (Iridaceae): origin and genetic composition of a homoploid hybrid species. American Journal of Botany 80 (5): 577-583.

Australian Weeds Committee (2009) Weeds of National Significance. Commonwealth of Australia. (http://www.weeds.org.au/docs/bb_index_and_introduction.pdf) (Downloaded 5 March 2010).

Ayres DE, Garcia-Rossi D, Davis HG \& Strong D.R. (1999) Extent and degree of hybridization between exotic (Spartina alterniflora) and native (S. foliosa) cordgrass (Poaceae) in California, USA determined by random amplified polymorphic DNA (RAPDs). Molecular Ecology 8: 1179-1186.

Blake ST (1954) Botanical contributions of the Northern Australian regional survey. 2. Studies on miscellaneous northern Australian plants. Australian Journal of Botany 2: 99-140.

Broué P (1973) Commonwealth plant introduction list No. 95. Plant Introduction Review 9(3): 25A.

Clayton WD, \& Renvoize SA (1986) Genera Graminum (Grasses of the World). (Royal Botanic Gardens, Kew)

Cowie I.D, Short PS \& Osterkamp Madsen M (2000) Floodplain Flora: a flora of the coastal floodplains of the Northern Territory, Australia. (ABRS, Canberra)

González-Rodríguez A, Arias DM, Valencia S \& Oyama K. (2004) Morphological and RAPD analysis of hybridization between Quercus affinis and Q. laurina (Fagaceae), two Mexican red oaks. American Journal of Botany 91 (3): 401-409.

Grass Phylogeny Working Group (2001) Phylogeny and subfamilial classification of the grasses (Poaceae), Annals of the Missouri Botanical Garden 88(3): 373-457.

Hegarty MJ \& Hiscock SJ (2005) Hybrid speciation in plants: new insights from molecular studies. New Phytologist 165: 411-423.

Kellogg EA (2002) Classification of the grass family. Pp. 19-36 in Mallett K \& Orchard AE (eds) Flora of Australia, vol. 43. Poaceae I. Introduction and Atlas. (ABRS, Canberra/CSIRO, Melbourne) 
Lee NS, Yeau SH, Park JO \& Roh MS (2006) Molecular evidence for hybridization of Ilex $\times$ wandoensis (Aquifoliaceae) by RAPD analysis. Journal of Plant Biology 49 (6): 491-497.

Oram RN (1989) Register of Australian Herbage Plant Cultivars. Australian Journal of Experimental Agriculture 29: 293.

Panigrahi G \& Dubey AK (1986) Notes on lectotypification of Hymenachne P.Beauv. (Poaceae). Taxon 35: 338-40.

Peterson A, Harpke D, Peruzzi L, Levichev I G, Tison J-M \& Peterson J (2009) Hybridization drives speciation in Gagea (Liliaceae). Plant Systematics and Evolution 278: 133-148.

Pohl RW \& Lersten NR (1975) Stem aerenchyma as a character separating Hymenachne and Sacciolepis (Gramineae, Panicoideae). Brittonia 27: 223-227.

Rauscher JT, Doyle JJ \& Brown AHD (2002) Internal transcribed spacer repeat-specific primers and the analysis of hybridization in the Glycine tomentella (Leguminosae) polyploidy complex. Molecular Ecology 11: 2691-2702.

Sun Y, Skinner DZ Liang GH \& Hulbert SH (1994) Phylogenetic analysis of Sorghum and related taxa using internal transcribed spacers of nuclear ribosomal DNA. Theoretical and Applied Genetics 89: 26-32.

Thompson JD, Higgins DG \& Gibson TJ (1994) CLUSTAL W: improving the sensitivity of progressive multiple sequence alignment through sequence weighting, position-specific gap penalties and weight matrix choice. Nucleic Acids Research 22: 4673-4680.

Torres Gonzalez AM \& Morton CM (2005) Molecular and morphological phylogenetic analysis of Brachiaria and Urochloa (Poaceae). Molecular Phylogenetics and Evolution 37: 36-44.

Webster RD (1987) The Australian Paniceae (Poaceae). (J Cramer: Stuttgart)

White CT (1932) 'Answer to correspondence - swamp grass'. Queensland Agricultural Journal 38: 372 .

Wearne LJ, Clarkson JR \& Vitelli JS (2010) The biology of Australian weeds. 56. Hymenachne amplexicaulis (Rudge) Nees. Plant Protection Quarterly 25: 146-161.

Yüzbaşioğlu E, Dadandi MY \& Özcan S (2008) Natural hybridization between Phlomis lycia D. Don $\times$ P. bourgaei Boiss., (Lamiaceae) revealed by RAPD markers. Genetica 133: 13-20.

Manuscript received 22 March 2010, accepted 26 October 2010

\section{Appendix 1. Vouchers for molecular studies.}

Abattoir Swamp, 4.5km north of Mount Molloy (16³8'09"S, 145¹9'37"E), 16 February 2009.

Hymenachne amplexicaulis (Rudge) Nees

Hymenachne acutigluma (Steud.) Gilliland

Hymenachne $\times$ calamitosa J.R. Clarkson
J.R. Clarkson 11787 (BRI).

J.R. Clarkson 11788 (BRI).

J.R. Clarkson 11789 (BRI).

Beatrice Creek east of Humpty Doo on the Arnhem Highway (12³8'30"S, 131¹8'34"E), 20 May 2009.

Hymenachne amplexicaulis (Rudge) Nees J.R. Clarkson 11790 (BRI).

Hymenachne $\times$ calamitosa J.R. Clarkson J.R. Clarkson 11791 (BRI).

Manton Dam ca 52 km south east of Darwin (1250'53"S, 131 07'36"E), 20 May 2009.

Hymenachne acutigluma (Steud.) Gilliland J.R. Clarkson 11792 (BRI).

Manton Dam ca 52 km south east of Darwin (1251'07"S, 13107'37"E), 20 May 2009.

Hymenachne amplexicaulis (Rudge) Nees

J.R. Clarkson 11793 (BRI). 